\title{
Determinants of Internet Entrepreneurship Intentions among Business School Students
}

\author{
Yu-Min Wang and Yi-Shuan Lin
}

\begin{abstract}
This study presents the findings of an empirical study to analyze factors affecting business school students' intentions to Internet entrepreneurship. An integrated model, based on Rogers' (1983) innovation diffusion theory, Ajzen's (1991) theory of planned behavior, and Internet entrepreneur characteristics, is proposed. A total of 107 business school students were surveyed. The research hypotheses were examined using multiple regression analysis. The results show that compatibility, subjective norm, and perceived behavioral control influence significantly the intention of business school students to Internet entrepreneurship. The research findings deepen our understanding of business school students' intentionss to become Internet entrepreneurs.
\end{abstract}

Index Terms-Internet entrepreneurship, innovation diffusion theory, theory of planned behavior.

\section{INTRODUCTION}

With the increasing popularity of the Internet and communication technologies, more and more consumers inquiry and purchase products on the Internet. By 2017 it is predicted that business-to-consumer electronic commerce (EC) sales revenue will reach about $\$ 2.36$ trillion dollars [1]. Furthermore, the emergent Internet commerce applications substantially reduce the costs of creating and operating a business [2]. Therefore, the booming EC creates an opportunity for Internet entrepreneurship. Internet entrepreneurs draw on their familiarity with the culture and technologies of the Internet in their attempts to develop businesses [2], [3]. While the promise of the low cost and high potentials of EC startup attracts entrepreneurs, the success rate is actually very low [4].

Understanding the formation of entrepreneurial intentions is important, because intention is an effective predictor of entrepreneurial behaviors [5], [6].

This paper reports an empirical study of the factors affecting business school students' intentions to Internet entrepreneurship. The results help researchers and educators to understand what enables and inhibits business school students' intentions to become Internet entrepreneurs.

\section{THEORETICAL BACKGROUND}

\section{A. Theory of Planned Behavior (TPB)}

Manuscript received February 15, 2015; revised May 7, 2015. This work was partially supported by the Ministry of Science and Technology in Taiwan under the grant MOST 103-2511-S-260 -002 -MY2.

The authors are with the National Chi Nan University, Taiwan (e-mail: ymwang@ncnu.edu.tw, s101213517@ncnu.edu.tw).
Ajzen's theory of planned behavior (TPB) is useful in explaining and predicting a wide range of behaviors [7]. The TPB (Fig. 1), asserts that attitude, subjective norm, and perceived behavioral control affect behavioral intention and this, in turn, affects actual behavior. Behavioral intention is a particularly reliable predictor of actual behavior. Attitude taps the individual's perception of the desirability of performing the intended behavior [8]. Subjective norm refers how an individual accounts for the judgment of important others about the planned behavior [9]. Perceived behavioral control describes an individual's perception of whether he or she has the necessary resources, capability, and sense of control in successfully performing the intended behavior [10]. Behavioral intention is a motivational factor that captures how hard a person is willing to try to perform a behavior [9].

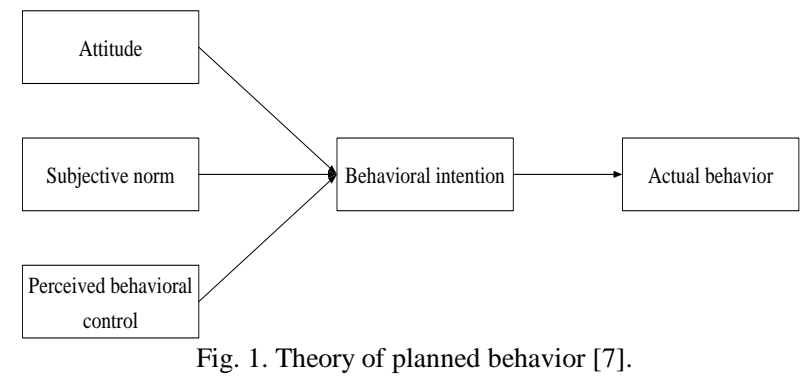

\section{B. Innovation Diffusion Theory (IDT)}

Researchers frequently draw on Rogers' innovation diffusion theory (IDT) [11]. to explain an individual's adoption of an innovation. Rogers identifies five innovative characteristics as antecedents to any adoption decision: relative advantage, compatibility, complexity, trialability, and observability. Relative advantage refers to the degree to which an innovation is considered as being better than the idea it supersedes. Compatibility is the degree to which an innovation is regarded as being consistent with the potential adopter's existing values, prior experiences, and needs [12]. Complexity is the degree to which an innovation is difficult to understand and perform [13]. Trialability is the extent to which an innovation can be tried out [14]. Observability refers to the degree to which the results of an innovation are visible to others [12].

\section{Summary}

There are many studies that successfully use TPB to analyze entrepreneurial intentions [8], [15], [16]. Therefore, TPB is used as the theoretical foundation for the research model of this study. However, some findings about the effect of attitude on intention have not always been significant [17], [18]. Hence, many researches ignored attitude [18], [19]. To maintain the research model brevity and parsimony, the 
current research only includes subjective norm and perceived behavioral control to explain behavioral intention in the model.

Innovation diffusion theory is also used as the theoretical foundation for this study because the theory can effectively explain the innovation adoption decision of an individual. Previous studies find that only relative advantage, compatibility, and complexity relate significantly to innovation adoption [20], [21]. Therefore, the three innovative characteristics - relative advantage, complexity, and compatibility are included in the research model in this study.

\section{RESEARCH MODEL AND HYPOTHESES}

Fig. 2 shows this study's research model. It is desirable to use the Internet entrepreneurship intention as the dependent variable in our study since intention is a strong indicator of behavior.

The model consists of five factors that are hypothesized to have direct effects on Internet entrepreneurship intention. Since this study focuses on identifying factors which can predict the intention to Internet entrepreneurship, the relationships among the five factors are not in our research scope.

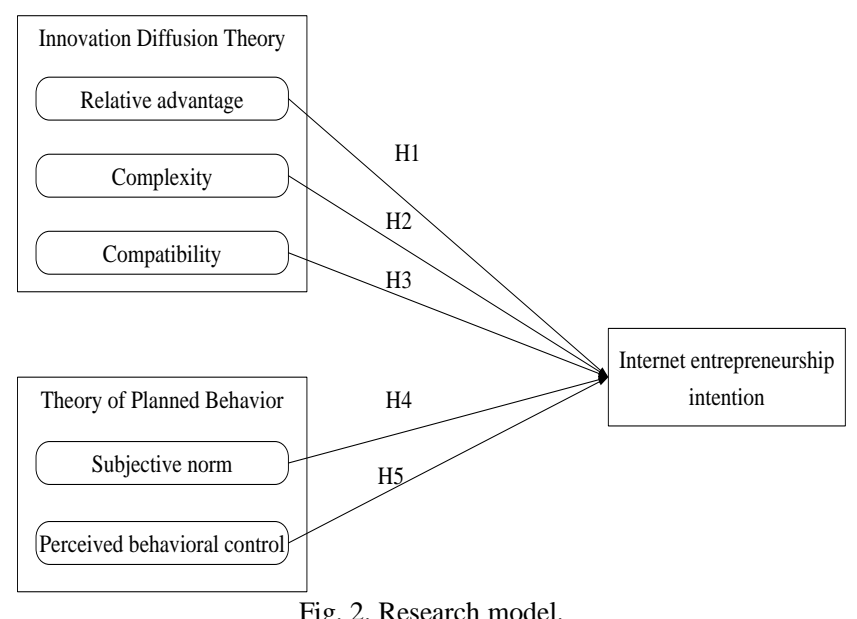

Based on the assertions of TPB and IDT, the following hypotheses are proposed:

H1: Relative advantage has a positive effect on the intention to Internet entrepreneurship.

$\mathrm{H} 2$ : Complexity has a negative effect on the intention to Internet entrepreneurship.

H3: Compatibility has a positive effect on the intention to Internet entrepreneurship.

H4: Subjective norm has a positive effect on the intention to Internet entrepreneurship.

H5: Perceived behavioral control has a positive effect on the intention to Internet entrepreneurship.

\section{ReSEARCH Methodology}

\section{A. Variable Measurement}

To ensure content validity, the measurement items were developed based on existing instruments. All measurement items were modified to fit the context of Internet entrepreneurship. The three IDT variables (i.e., relative advantage, complexity, compatibility) were taken from Moore and Benbasat [22] and Wang et al. [13]. The two TPB predictors (i.e., subjective norm and perceived behavioral control) were adapted from Taylor and Todd [17]. Internet entrepreneurship intention was captured using three items derived from Venkatesh et al. [18]. A five-point Likert scale that ranged from 1, "strongly disagree," to 5, "strongly agree," was used for all the items that measured the six variables.

\section{B. Data Collection and Sample Characteristics}

Data for this study were collected using a questionnaire survey. A total of 107 business school students agreed to participate in the survey. The respondents were 50.5 percent male and had an average age of 22.3 years (Table I).

TABLE I: SAMPLE PROFILE

\begin{tabular}{lcclcc}
\hline \hline Demographics & Frequency & $\%$ & Demographics & Frequency & $\%$ \\
\hline Gender & & & Age & \\
Male & 54 & 50.5 & 20 or less & 33 & 30.8 \\
Female & 53 & 49.5 & $21-30$ & 73 & 68.2 \\
& & & 30 and above & 1 & .9 \\
\hline \hline
\end{tabular}

\section{DATA ANALYSIS AND RESUlts}

\section{A. Reliability and Validity}

TABLE II: ROTATED FACTOR MATRIX AND ALPHA COEFFICIENTS

\begin{tabular}{|c|c|c|c|c|c|c|}
\hline Items & RA & $\mathrm{CM}$ & $\mathrm{CO}$ & SN & $\mathrm{PBC}$ & IEI \\
\hline RA1 & .74 & & & & & \\
\hline RA2 & .65 & & & & & \\
\hline RA3 & .58 & & & & & \\
\hline RA4 & .83 & & & & & \\
\hline CM1 & & .83 & & & & \\
\hline $\mathrm{CM} 2$ & & .82 & & & & \\
\hline CM3 & & .55 & & & & \\
\hline $\mathrm{CO} 1$ & & & .69 & & & \\
\hline $\mathrm{CO} 2$ & & & .83 & & & \\
\hline $\mathrm{CO} 3$ & & & .76 & & & \\
\hline $\mathrm{CO} 4$ & & & .78 & & & \\
\hline $\mathrm{CO} 5$ & & & .88 & & & \\
\hline SN1 & & & & .70 & & \\
\hline SN2 & & & & .86 & & \\
\hline SN3 & & & & .86 & & \\
\hline PBC1 & & & & & .68 & \\
\hline $\mathrm{PBC} 2$ & & & & & .67 & \\
\hline $\mathrm{PBC} 3$ & & & & & .82 & \\
\hline IEI1 & & & & & & .86 \\
\hline IEI2 & & & & & & .87 \\
\hline IEI3 & & & & & & .79 \\
\hline$\alpha$ coefficient & .80 & .67 & .91 & .89 & .87 & .96 \\
\hline
\end{tabular}

Note: (1) The definitions of all items are in the Table III. (2) RA: relative advantage, CM: complexity, CO: compatibility, SN: subjective norm, PBC: perceived behavioral control, IEI: Internet entrepreneurship intention.

Exploratory factor analysis was used to assess the validity of the construct measures. The 107 responses were examined using a principal-components factor analysis as the extraction technique and Varimax as the orthogonal rotation method. Three rules were applied in order to identify a lack of fit between the items and their constructs: 1) the item had an eigenvalue less than 1,2) all factor loadings of the item were 
less than 0.5 , and 3) items that had two or more factor loadings that were greater than 0.5 (i.e., cross-loadings) [23]. The process of evaluating the fit of items to their constructs was repeated. Table II shows the factor matrix and Cronbach's alpha coefficients, and Table III shows the measurement items of the variables. All coefficients for the six constructs in this study are higher than 0.65 .

The item-to-total correlation is the extent to which each measure item correlates with the total score of its pertinent factor [24]. The item-to-total correlation was used to assess the construct validity. A high item-to-total correlation indicates that the item loads on its intended construct [25]. Table IV shows that all item-to-total correlations exceed 0.5 and are significant at $p<0.001$. This indicates a good level of validity of the measurement constructs.

\section{B. Descriptive Statistics}

The composite scores of the six constructs were calculated by averaging the original item scores. Table $\mathrm{V}$ shows the descriptive statistics and inter-correlations for the six constructs.

TABLE III: CONSTRUCTS AND MEASUREMENT ITEMS

\begin{tabular}{|c|c|}
\hline Constructs & $\overline{\text { Items }}$ \\
\hline Relative advantage & $\begin{array}{l}\text { RA1. I think that Internet entrepreneurship can } \\
\text { stimulate my potentials to handle challenges. } \\
\text { RA2. I think that Internet entrepreneurship can exhibit } \\
\text { my abilities. } \\
\text { RA3. I believe that Internet entrepreneurship can let me } \\
\text { make considerable incomes. } \\
\text { RA4. I think that Internet entrepreneurship can make me } \\
\text { grow. }\end{array}$ \\
\hline Complexity & $\begin{array}{l}\text { CM1. I think that Internet entrepreneurship is risky. } \\
\text { CM2. Internet entrepreneurship requires a lot of mental } \\
\text { efforts. } \\
\text { CM3. I believe that Internet entrepreneurship is } \\
\text { difficult. }\end{array}$ \\
\hline Compatibility & $\begin{array}{l}\text { CO1. I think that Internet entrepreneurship fits well with } \\
\text { the work that I like. } \\
\text { CO2. Internet entrepreneurship fits into my work style. } \\
\text { CO3. I think that I like Internet, therefore I want to start } \\
\text { business on the Internet. } \\
\text { CO4. I think that Internet entrepreneurship is } \\
\text { compatible with the work model that I expect. } \\
\text { CO5. I think that Internet entrepreneurship fits well with } \\
\text { the work habit that I like. }\end{array}$ \\
\hline Subjective norm & $\begin{array}{l}\text { SN1. My friends or family think that I can start a } \\
\text { business on the Internet. } \\
\text { SN2. My friends or family think that I should start an } \\
\text { Internet business. } \\
\text { SN3. My friends or family think that I must start a } \\
\text { business on the Internet }\end{array}$ \\
\hline $\begin{array}{l}\text { Perceived } \\
\text { behavioral control }\end{array}$ & $\begin{array}{l}\text { PBC1. I have sufficient resources for Internet } \\
\text { entrepreneurship. } \\
\text { PBC2. I think that I have the knowledge for Internet } \\
\text { entrepreneurship. } \\
\text { PBC3. I have some requisite resources to start a business } \\
\text { on the Internet. }\end{array}$ \\
\hline $\begin{array}{l}\text { Internet } \\
\text { entrepreneurship } \\
\text { intention }\end{array}$ & $\begin{array}{l}\text { IEI1. I will start a business on the Internet in the future. } \\
\text { IEI2. I intend to start an Internet business. } \\
\text { IEI3. I plan to start a business on the Internet in the } \\
\text { future }\end{array}$ \\
\hline
\end{tabular}

TABLE IV: ITEM-TO-TOTAL CORRELATIONS BETWEEN EACH ITEM AND ITS RELATIVE FACTOR

\begin{tabular}{lcc}
\hline \hline \multicolumn{1}{c}{ Items } & Relative Factor & Correlation \\
\hline RA1 & Relative advantage & .84 \\
RA2 & Relative advantage & .79 \\
RA3 & Relative advantage & .75 \\
RA4 & Relative advantage & .79 \\
CM1 & Complexity & .76 \\
CM2 & Complexity & .77 \\
CM3 & Complexity & .77 \\
CO1 & Compatibility & .83 \\
CO2 & Compatibility & .88 \\
CO3 & Compatibility & .86 \\
CO4 & Compatibility & .87 \\
CO5 & Compatibility & .87 \\
SN1 & Subjective norm & .86 \\
SN2 & Subjective norm & .94 \\
SN3 & Subjective norm & .90 \\
PBC1 & Perceived behavioral control & .76 \\
PBC2 & Perceived behavioral control & .79 \\
PBC3 & Perceived behavioral control & .61 \\
IEI1 & Internet entrepreneurship intention & .94 \\
IEI2 & Internet entrepreneurship intention & .97 \\
IEI3 & Internet entrepreneurship intention & .95 \\
\hline \hline
\end{tabular}

$\overline{\text { Note: (1) The definitions of all items are in the Table III. (2) All significance }}$ levels are less than 0.001 .

TABLE V: DESCRIPTIVE STATISTICS AND INTER-CORRELATIONS

\begin{tabular}{lcccccccc}
\hline \hline & \multirow{2}{*}{ Mean } & \multirow{2}{*}{ SD } & \multicolumn{7}{c}{ Correlations } \\
\cline { 5 - 9 } & & & RA & CM & CO & SN & PBC & IEI \\
RA & 3.70 & .60 & 1 & .36 & .56 & .43 & .41 & .44 \\
CM & 4.14 & .57 & .36 & 1 & .21 & .05 & .08 & .07 \\
CO & 3.37 & .72 & .56 & .21 & 1 & .45 & .46 & .53 \\
SN & 2.95 & .82 & .43 & .05 & .45 & 1 & .61 & .43 \\
PBC & 3.05 & .88 & .41 & .08 & .46 & .61 & 1 & .65 \\
IEI & 3.00 & .88 & .44 & .07 & .53 & .43 & .65 & 1 \\
\hline \hline
\end{tabular}

Note: RA: relative advantage, CM: complexity, CO: compatibility, SN: subjective norm, PBC: perceived behavioral control, IEI: Internet entrepreneurship intention.

\section{Hypotheses Testing}

Multiple regression analysis was used to test the hypotheses in this study. Prior to analysis, three tests were run to examine the suitability of the data for regression analysis. First, we examine if the ratio of sample size to predictor number (21.4:1) was higher than the recommended minimum (i.e., 20:1). Our data satisfies this criteria thereby ensuring generalizability [26]. Second, the data was evaluated to see if it met the expectation of a normal distribution. The ratio of skewness and kurtosis to the respective standard errors should fall within the interval of $[-1.96,1.96]$ at significance level of 0.05 [27]. Table VI, the results of the normality test, shows that all variables in this study follow a normal distribution.

TABLE VI: THE NORMALITY TEST

\begin{tabular}{lcccccc}
\hline \hline & RA & CM & CO & SN & PBC & IEI \\
\hline Skewness / Standard error & -.44 & -1.66 & 1.00 & .57 & 1.67 & .19 \\
Kurtosiss / Standard error & -.67 & .73 & -.26 & .72 & .73 & .10 \\
\hline \hline Note: RA: relative advantage, CM: complexity, CO: compatibility, SN: \\
subjective norm, PBC: perceived behavioral control, IEI: Internet \\
entrepreneurship intention.
\end{tabular}

Third, the data was examined whether multicollinearity existed. Multicollinearity occurs when independent variables are highly correlated with each other [28]. This will result in 
incorrect parameter estimates in regression models [29]. Table $\mathrm{V}$ shows the inter-correlations for the five predictors. There is no correlation greater than the threshold value of 0.9 between predictors [26]. The tolerance value and the variance inflation factor (VIF) were also used to assess both pairwise and multiple variable collinearity (i.e., multicollinearity). Table VII shows the results of the multicollinearity tests. All the tolerance values exceed 0.1 and all the VIF are below 10 [26]. Taken together, these results indicate that multicollinearity does not pose a serious problem in this study.

TABLE VII: THE MULTICOLLINEARITY TEST

\begin{tabular}{llllll}
\hline \hline & RA & CM & CO & SN & PBC \\
\hline Tolerance & .56 & .84 & .68 & .77 & .71 \\
VIF & 1.80 & 1.19 & 1.48 & 1.30 & 1.42 \\
\hline \hline
\end{tabular}

Note: RA: relative advantage, CM: complexity, CO: compatibility, SN: subjective norm, PBC: perceived behavioral control, IEI: Internet entrepreneurship intention.

Multiple regression analysis with the forced entry method (also referred to as the all-variables-together method) was employed to test the hypotheses. The Durbin-Watson statistic is 1.96 , which is within the acceptable range of 1.5 to 2.5 [30]. The results show that each error term is independent. That is, no auto-correlation problems are detected within the regression model. The analysis of variance (ANOVA) assesses whether the regression model is a significant fit with the data [27]. Table VIII shows the value is significant $(F=$ 22.96; $p<0.001)$. The ANOVA result reveals a good fit between the data and the regression model.

TABLE VIII: RESULTS OF THE ANOVA TEST

\begin{tabular}{lcrccc}
\hline \hline \multicolumn{1}{c}{ Model } & $\begin{array}{c}\text { Sum of } \\
\text { Squares }\end{array}$ & $d f$ & $\begin{array}{c}\text { Mean } \\
\text { Square }\end{array}$ & $F$ & Sig. \\
\hline Regression & 43.92 & 5 & 8.78 & 22.96 & .000 \\
Residual & 38.63 & 101 & .38 & & \\
Total & 82.55 & 106 & & & \\
\hline \hline
\end{tabular}

TABLE IX: RESULTS OF MULTIPLE REGRESSION

\begin{tabular}{|c|c|c|c|c|}
\hline \multirow{2}{*}{ Predictor } & \multicolumn{2}{|c|}{ Unstandardized coefficients } & \multirow{2}{*}{$\begin{array}{c}\text { Standardized } \beta \\
\text { coefficients }\end{array}$} & \multirow{2}{*}{$t$} \\
\hline & B & SE & & \\
\hline Constant & -.47 & .59 & & \\
\hline RA & .03 & .14 & .02 & .25 \\
\hline $\mathrm{CM}$ & .05 & .13 & .03 & .37 \\
\hline $\mathrm{CO}$ & .33 & .10 & .29 & $3.49 * *$ \\
\hline $\mathrm{SN}$ & .19 & .09 & .16 & $2.08 *$ \\
\hline PBC & .49 & .09 & .46 & $5.67 * * *$ \\
\hline
\end{tabular}

Note: $(1) * p<0.05, * * p<0.01, * * * p<0.001$. (2) RA: relative advantage, CM complexity, CO: compatibility, SN: subjective norm, PBC: perceived behavioral control.

Table IX shows the parameter estimates of the regression analysis. A two-tailed $P$ value of $<0.05$ was considered statistically significant. The sign of the standardized regression coefficient $(\beta)$ represents the positive or negative impact of the independent variables on the dependent variable. The five-predictor model explains $53.2 \%$ of the variation in business school students' intentions to Internet entrepreneurship. Three factors (compatibility, subjective norm, and perceived behavioral control) are significant at the 0.05 level. The results provide evidence to support Hypotheses 3, 4, and 5. Compatibility, subjective norm, and perceived behavioral control are significant and positively relate to individual's intention to Internet entrepreneurship. Relative advantage and complexity do not predict intentions to entrepreneurship and therefore Hypotheses 1 and 2 are not supported.

\section{DISCUSSION}

\section{A. IDT Constructs}

The majority of prior studies find that relative advantage, complexity, and compatibility have a significant effect on individuals' innovation adoption [21]. By contrast, in this study, we find that only compatibility determines significantly business school students' intentions to Internet entrepreneurship.

There may be two reasons why complexity does not determine significantly business students' intentions to Internet entrepreneurship First, business school students are required to take courses relating to use of the Internet for business in universities. Furthermore, students' own experiences of using e-commerce platforms mean they do not perceive complexity as a barrier to online entrepreneurship. Second, the availability and user-friendliness of Internet application toolkits and $\mathrm{C} 2 \mathrm{C}$ online shopping platforms (e.g., Taobao and eBay) may mask the underlying technical complexities that enable Internet entrepreneurship.

Compatibility does influence business school students' intentions to Internet entrepreneurship. Compatibility reflects the level of one's perceptions about the reconcilability of an innovation with existing practices, habits, and preferences. Business school students are young. Therefore, they prefer freedom and do not like restriction. Internet entrepreneurship may be drawn to the high level of work freedom and flexibility that seems integral to entrepreneurship on the Internet. Internet entrepreneurship is compatible with the life styles and preferences of business school students.

Relative advantage does not affect significantly the intention to Internet entrepreneurship. One possible explanation for this result is that cases of successful Internet entrepreneurship are particularly visible while failures are largely obscured. This leaves students with the impression that the risks of Internet entrepreneurship are low and success almost inevitable.

\section{B. TPB Constructs}

The intention to Internet entrepreneurship is affected significantly by subjective norm and perceived behavioral control. The results are consistent with the prior studies regarding entrepreneurship intention. Most business school students are still in the stage of establishing their career choice preferences. The opinions of important others; such as, friends, parents, teachers and classmates, likely influence this process [16]. Business school students also are likely to perceive that they have sufficient resources and capabilities (i.e., a sense of control).

\section{CONCLUSION}

This study applies TPB and IDT to analyze the determinants of business school students' intentions to Internet entrepreneurship. The results of this study extend our 
understanding regarding Internet entrepreneurship intentions in three ways.

1) Compatibility, subjective norm, and perceived behavioral control have effects positively and significantly on the business school students' intentions to Internet entrepreneurship.

2) Perceived behavioral control is the most influential determinants of business school students' intentions to Internet entrepreneurship.

3) The two important IDT constructs (i.e., relative advantage and complexity) are not influences that significantly explain intention to Internet entrepreneurship.

The study presented here has several limitations that also represent opportunities for future research. First, this study only focused on the single relationships between the predictor and the explained variable (i.e., intention). Therefore, the interrelated relationships among the predictors (e.g., complexity may affect relative advantage) were not analyzed in this study. Future research should examine these dependence relationships simultaneously. Second, this study used a convenience sample in Taiwan. Thus, we need to exercise caution when generalizing our findings. Samples from different countries or groups should be gathered to validate the proposed model and findings.

In the future, a survey can be conducted to collect data from full-time employees. This will enable a comparison between students and employees. More implications and insights about Internet entrepreneurship will be obtained

\section{REFERENCES}

[1] T. Mavlanova, "The effect of cultural values on the perceptions of architectural quality of websites in e-commerce," presented at the SIGHCI Conference on Human Factors in Computing Systems, 2014

[2] C. Millman, W. C. Wong, Z. Li, and H. Matlay, "Educating students for e-entrepreneurship in the UK, the USA and China," Industry and Higher Education, 2009, vol. 23, no. 3, pp. 243-252.

[3] (2013). Internet entrepreneur job description, career as an Internet entrepreneur, salary, employment-definition and nature of the work, education and training requirements, getting the job. [Online]. Available: http://careers.stateuniversity.com/pages/215/ Internet-Entrepreneur.html

[4] B. Foster. (2013). Internet entrepreneur. [Online]. Available: http://www.business-solutions-and-resources.com/internet-entreprene ur.html

[5] B. Bird, "Implementing entrepreneurial ideas: The case for intention," Academy of Management Review, vol. 13, no. 3, pp. 442-453, 1988.

[6] S. Shane and S. Venkataraman, "The promise of entrepreneurship as a field of research," Academy of Management Review, vol. 25, no. 1, pp. 217-226, 2000.

[7] I. Ajzen, "The theory of planned behavior," Organizational Behavior and Human Decision Processes, vol. 50, no. 2, pp. 179-211, 1991.

[8] P. A. Pavlou and M. Fygenson, "Understanding and predicting electronic commerce adoption: An extension of the theory of planned behavior," MIS Quarterly, vol. 30, no. 1, pp. 115-143, 2006.

[9] N. F. Krueger, M. D. Reilly, and A. L. Carsrud, "Competing models of entrepreneurial intentions," Journal of Business Venturing, vol. 15, no. 5-6, pp. 411-432, 2000.

[10] Y. Lu, T. Zhou, and B. Wang, "Exploring Chinese users' acceptance of instant messaging using the theory of planned behavior, the technology acceptance model, and the flow theory," Computers in Human Behavior, 2009, vol. 25, no. 1, pp. 29-39.

[11] E. M. Rogers, Diffusion of Innovations, $3^{\text {rd }}$ ed., New York: The Free Press, 1983.

[12] Y. H. Lee, Y. C. Hsieh, and C. N. Hsu, "Adding innovation diffusion theory to the technology acceptance model: Supporting employees' intentions to use e-learning systems," Educational Technology \& Society, vol. 14, no. 4, pp. 124-137, 2011.
[13] Y. S. Wang et al., "Determinants of user adoption of web automatic teller machines: An integrated model of transaction cost theory and innovation diffusion theory," Service Industries Journal, vol. 32, no. 9, pp. 1505-1525, 2012.

[14] A. D. Carswell and V. Venkatesh, "Learner outcomes in an asynchronous distance education environment," International Journal of Human-Computer Studies, vol. 56, no. 5, pp. 475-494, 2002.

[15] J. R. Fitzsimmons and E. J. Douglas, "Interaction between feasibility and desirability in the formation of entrepreneurial intentions," Journal of Business Venturing, vol. 26, no. 4, pp. 431-440, 2011.

[16] M. van Gelderen et al., "Explaining entrepreneurial intentions by means of the theory of planned behavior," Career Development International, 2008, vol. 13 , no. 6, pp. 538-559.

[17] S. Taylor and P. A. Todd, "Assessing IT usage: The role of prior experience," MIS Quarterly, vol. 19, no. 4, pp. 561-570, 1995.

[18] V. Venkatesh, M. Morris, G. B. Davis, and F. D. Davis, "User acceptance of information technology: Toward a unified view," MIS Quarterly, vol. 27, no. 3, pp. 425-478, 2003.

[19] V. Venkatesh and F. D. Davis, "A theoretical extension of the technology acceptance model: Four longitudinal field studies," Management Science, vol. 45, no. 2, pp. 186-200, 2000.

[20] J. M. Kolodinsky, J. M. Hogarth, and M. A. Hilgert, "The adoption of electronic banking technologies by US consumers," The International Journal of Bank Marketing, vol. 22, no. 4, pp. 238-259, 2004.

[21] L. G. Tornatzky and K. J. Klein, "Innovation characteristics and innovation adoption-implementation: A meta-analysis of findings," IEEE Transactions on Engineering Management, vol. 29, no. 1, pp. $28-45,1982$

[22] G. C. Moore and I. Benbasat, "Development of an instrument to measure the perceptions of adopting an information technology innovation," Information Systems Research, vol. 2, no. 3, pp. 192-222, 1991.

[23] V. Sethi and W. R. King, "Construct measurement in information systems research: An illustration in strategic systems," Decision Sciences, vol. 22, pp. 455-472, 1991.

[24] A. R. Montazemi, D. A. Cameron, and K. M. Gupta, "An empirical study of factors affecting software package selection, Journal of Management Information Systems, vol. 13, no. 1, pp. 89-105, 1996.

[25] M. Aldhmour and M. B. Eleyan, "Factors influencing the successful adoption of decision support systems: The context of Aqaba special economic zone authority," International Journal of Business and Management, vol. 7, no. 2, pp. 163-178, 2012.

[26] J. F. Hair, R. E. Anderson, R. L. Tatham, and W. Black, Multivariate Data Analysis, $5^{\text {th }}$ ed., Englewood: Prentice Hall, 1998.

[27] A. Field, Discovering Statistics Using SPSS, London: Sage Publications Ltd, 2009.

[28] V. Mahajan, A. Jain, and M. Bergier, "Parameter estimation in marketing models in the presence of multicollinearity," Journal of Marketing Research, vol. 14, no. 4, pp. 586-591, 1977.

[29] B. K. Slinker and S. A. Glantz, "Multiple regression for physiological data analysis: The problem of multicollinearity," American Journal of Physiology - Regulatory, Integrative and Comparative Physiology, vol. 249 , no. 1, pp. 1-12, 1985

[30] S. J. Coake et al., SPSS: Analysis without Anguish Using SPSS Version 11 for Windows, Brisbane, Australia: John Wiley and Sons, 2003.

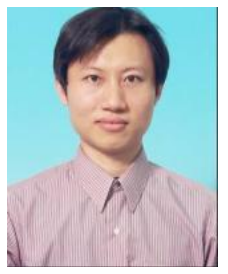

Yu-Min Wang is an associate professor in information management at National Chi Nan University in Taiwan. He received his Ph.D. degree in information management at National Sun Yat-Sen University in Taiwan. His research interests include enterprise information system, information system adoption, electronic commerce, e-learning, and knowledge management. His work has been published in academic journals such as Information \& Management, Computers in Human Behavior, International Journal of Operation \& Production Management etc.

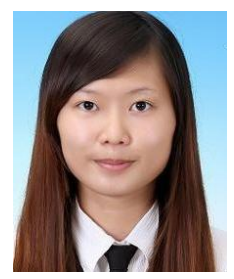

Yi-Shuan Lin is a graduate student in National Chi Nan University. She is interested in information management and entrepreneurship. 